\title{
Analysis of the Direct and Indirect Effects of Nanoparticle Exposure on Microglial and Neuronal Cells In Vitro
}

\author{
Jasna Lojk ${ }^{1,2, *, \dagger}$, Lea Babič ${ }^{1,3,+}$, Petra Sušjan ${ }^{3}$, Vladimir Boštjan Bregar ${ }^{1}$, Mojca Pavlin ${ }^{1,2}$, \\ Iva Hafner-Bratkovič ${ }^{3,4}{ }^{-1}$ and Peter Veranič ${ }^{5}$ \\ 1 Group for Nano and Biotechnological Applications, Faculty of Electrical Engineering, \\ University of Ljubljana, Trzaska cesta 25, 1000 Ljubljana, Slovenia; babic.lea994@gmail.com (L.B.); \\ vladimir.bregar@kolektor.com (V.B.B.); mojca.pavlin@fe.uni-lj.si (M.P.) \\ 2 Institute of Biophysics, Faculty of Medicine, University of Ljubljana, Vrazov trg 2, 1000 Ljubljana, Slovenia \\ 3 Department of Synthetic Biology and Immunology, National Institute of Chemistry, Hajdrihova ulica 19, \\ 1000 Ljubljana, Slovenia; petra.susjan@ki.si (P.S.); iva.hafner@ki.si (I.H.-B.) \\ 4 EN-FIST Centre of Excellence, Trg Osvobodilne fronte 13, 1000 Ljubljana, Slovenia \\ 5 Institute of Cell Biology, Faculty of Medicine, University of Ljubljana, Vrazov trg 2, 1000 Ljubljana, Slovenia; \\ peter.veranic@mf.uni-lj.si \\ * Correspondence: jasna.lojk@ffa.uni-lj.si \\ + These authors contributed equally to this work.
}

Received: 5 July 2020; Accepted: 21 September 2020; Published: 24 September 2020

\begin{abstract}
Environmental or biomedical exposure to nanoparticles (NPs) can results in translocation and accumulation of NPs in the brain, which can lead to health-related problems. NPs have been shown to induce toxicity to neuronal cells through several direct mechanisms, but only a few studies have also explored the indirect effects of NPs, through consequences due to the exposure of neighboring cells to NPs. In this study, we analysed possible direct and indirect effects of NPs (polyacrylic acid (PAA) coated cobalt ferrite NP, $\mathrm{TiO}_{2} \mathrm{P} 25$ and maghemite NPs) on immortalized mouse microglial cells and differentiated CAD mouse neuronal cells in monoculture (direct toxicity) or in transwell co-culture system (indirect toxicity). We showed that although the low NP concentrations $(2-25 \mu \mathrm{g} / \mathrm{mL})$ did not induce changes in cell viability, cytokine secretion or NF- $\mathrm{kB}$ activation of microglial cells, even low NP concentrations of $10 \mu \mathrm{g} / \mathrm{mL}$ can affect the cells and change their secretion of protein stress mediators. These can in turn influence neuronal cells in indirect exposure model. Indirect toxicity of NPs is an important and not adequately assessed mechanism of NP toxicity, since it not only affects cells on the exposure sites, but through secretion of signaling mediators, can also affect cells that do not come in direct contact with NPs.
\end{abstract}

Keywords: nanoparticle; neurotoxicity; ROS; cytokine secretion; microglia; co-culture

\section{Introduction}

In recent decades, exposure to nanoparticles (NPs) has significantly increased due to industrial development, increased motor transportation and increased number of engineered NPs used in different consumer products and biomedical applications [1]. Such NPs can enter and accumulate in the body, where they can cause different health-related problems, as indicated by several in vivo animal studies and human epidemiological studies, showing association between ambient/personal exposure to ultrafine particles and adverse health symptoms [2-4], including neurotoxicity. Moreover, the incidence of primary brain tumors, developmental and neurodegenerative diseases has increased in the last decades [5]. The exact etiology of these diseases is unknown, but environmental pollutants, 
including NPs, are frequently mentioned as one of the risk factors $[5,6]$. Recent studies reported finding combustion derived magnetite NPs in the brains of Alzheimer's patients [7,8], but no such studies have been conducted for engineered NPs. Unfortunately, research of the potential health risks of NP exposure lags behind the rapid industrial development and commercialization of nanotechnology.

Although the expected accumulation of NPs in the brain is low due to effective protective barriers, even such concentrations can be problematic owing to the specificity of brain tissue. Due to the limited ability of immune and clearance systems in the brain, NPs tend to accumulate and induce cell stress for prolonged time periods, which can cause chronic oxidative stress and inflammation, potentially leading to neurodegenerative changes [6,9]. However, recent studies showed that NPs cannot cause damage only directly, but also indirectly through changes in cell signaling and cell communication between different cell types [10-12], or even through intact cellular barriers [13,14].

Microglial cells are the resident innate immune cells, which play an important role in protection of the brain. Consequently, endocytosis of NPs in mixed neural cell cultures mainly occurs in microglial cells $[15,16]$, which are thus the main responders to the toxic insult. However, prolonged and uncontrolled activation of microglial cells may result in direct toxicity to neurons and astrocytes, mainly through secreted reactive oxygen species (ROS), nitric oxide (NO), cytokines and other signaling molecules [17-19].

Microglial cells can also be activated by NPs [20-23] and through their reaction affect neuronal cells, as suggested by some recent studies. For example, Neubert and coworkers showed that presence of primary mouse microglial cells in direct co-culture with mouse primary neuronal cells reduces neurite damage compared to neurite mono-cultures when incubated with different iron oxide NPs, most probably due to NP removal by microglial cells [24]. On the other hand, Hsiao el al showed that indirect exposure to high concentrations of $\mathrm{TiO}_{2} \mathrm{NPs}(30-100 \mu \mathrm{g} / \mathrm{mL})$ induced more neuronal damage in co-culture model with LPS activated BV-2 microglial cells compared to direct exposure of neuronal cells alone [25]. Similar results were obtained also for silver NPs [26]. Another study showed that conditioned medium from microglial cells stimulated with high concentrations $(500 \mu \mathrm{g} / \mathrm{mL})$ of $\mathrm{TiO}_{2}$ or hydroxyapatite NPs, but not $\mathrm{SiO}_{2}$ and iron oxide NPs, reduced the viability of PC12 neuronal cells [27]. Another in vitro study on primary cultures of rat brain striatum, which contained several cell types, indicated that microglial cells exposed to $\mathrm{TiO}_{2} \mathrm{NPs}$ generated ROS, which induced damage and apoptosis in neuronal cells [28]. These studies stress the importance of cell interactions in physiologically more relevant co-culture models on direct and indirect toxicity of NPs, which are not studied enough.

The purpose of this in vitro study was to analyse the possible direct and indirect toxic effect of NPs in mouse neural co-cultures. Mouse microglial and differentiated mouse neuronal CAD cells were incubated with selected NPs that could potentially reach the central nervous system; polyacrylic acid (PAA) coated cobalt ferrite $\mathrm{NP}, \mathrm{TiO}_{2} \mathrm{P} 25$ and uncoated maghemite (MGH) NPs. In contrast to most existing studies, low $(2-25 \mu \mathrm{g} / \mathrm{mL})$, physiologically more relevant concentrations were used to better assess the potential toxicity that such NPs could represent in vivo. We analysed cell viability and confirmed NP uptake in both cell lines and assessed potential activation of microglial cells through analysis of ROS generation and cytokine secretion. The indirect toxicity was analysed in a microglial/neuronal co-culture using the transwell system.

\section{Results}

The aim of this study was to assess the ability of NPs to cause direct or indirect damage on neuronal cells through activation of microglial cells in vitro. Three types of NPs were selected; uncoated MGH NPs as an example of environmentally present exhaust NPs, PAA coated cobalt ferrite NPs as an example of biomedical NPs [29-31] and $\mathrm{TiO}_{2}$ P25 NPs as an example of industrial NPs present in different coatings and materials [32]. Low concentrations of NPs (2 and $10 \mu \mathrm{g} / \mathrm{mL})$ were used in order to more closely resemble possible in vivo exposure and accumulation, respectively, and higher $(25 \mu \mathrm{g} / \mathrm{mL})$ was used to assess possible effect that are too subtle at $2-10 \mu \mathrm{g} / \mathrm{mL}$ and for easier comparison with literature. 


\subsection{Nanoparticle Characterization}

NPs were characterized in distilled water and cell culture media used for the experiments. The size of NPs (Z-average, hydrodynamic diameter) and polydispersity index (PDI) increased in cell culture media compared to water dispersions (Table 1, Figure S1), most probably due to higher aggregation triggered by the presence of counter ions and formation of protein corona. Protein corona formation also affected the Zeta potential of NPs. Independently of the effective surface charge of NPs in water suspension ( $37.5 \mathrm{mV}$ for $\mathrm{TiO}_{2} \mathrm{P} 25,-50.5 \mathrm{mV}$ for PAA and $39.1 \mathrm{mV}$ for MGH NPs), the Zeta potential in cell culture medium was negative and ranged from -9 to $-18 \mathrm{mV}$, which is closer to the net Zeta potential of serum proteins $(-7 \mathrm{mV}$ ) (Table 1$)$. While PAA and MGH NPs remained relatively stable despite slight aggregation in cell culture medium, $\mathrm{TiO}_{2}$ P25 NPs aggregated and slowly sedimented. The measurements given in Table 1 thus represent mainly the fraction that remained stable during time frame of the measurement.

Table 1. Z-average size, hydrodynamic diameter, polydispersity index (PDI) values and Zeta potential of industrial-grade $\mathrm{TiO}_{2} \mathrm{P} 25$, maghemite (MGH) and polyacrylic acid (PAA) coated cobalt ferrite nanoparticles in distilled water and DMEM cell culture medium supplemented with $10 \%$ foetal bovine serum (FBS). Mean and standard deviation are shown for two separate measurements.

\begin{tabular}{|c|c|c|c|c|c|}
\hline & $\begin{array}{l}\text { Dispersion } \\
\text { Media }\end{array}$ & $\begin{array}{c}\text { Z-Average Size } \\
(\mathrm{nm})\end{array}$ & $\begin{array}{l}\text { Hydrodynamic } \\
\text { Diameter }(\mathrm{nm})^{a}\end{array}$ & PDI & $\begin{array}{c}\text { Zeta Potential } \\
(\mathrm{mV})\end{array}$ \\
\hline \multirow{2}{*}{ PAA } & $\mathrm{dH}_{2} \mathrm{O}$ & $239.6 \pm 41.6$ & $64.5 \pm 19.1$ & $0.366 \pm 0.009$ & $-50.5 \pm 5$ \\
\hline & Medium & $346.0 \pm 49.0$ & $59.5 \pm 12.2$ & $0.545 \pm 0.057$ & $-17.8 \pm 0.6$ \\
\hline \multirow{2}{*}{ MGH } & $\mathrm{dH}_{2} \mathrm{O}$ & $128.8 \pm 1.1$ & $35.3 \pm 3.7$ & $0.196 \pm 0.008$ & $39.1 \pm 1.9$ \\
\hline & Medium & $243.9 \pm 1.1$ & $67.6 \pm 33.6$ & $0.291 \pm 0.015$ & $-9.8 \pm 0.5$ \\
\hline \multirow{2}{*}{$\mathrm{TiO}_{2} \mathrm{P}_{25}$ * } & $\mathrm{dH}_{2} \mathrm{O}$ & $270.1 \pm 6.6$ & $92.3 \pm 19.8$ & $0.356 \pm 0.002$ & $37.5 \pm 0.5$ \\
\hline & Medium & $406.5 \pm 18.6$ & $197.7 \pm 10.7$ & $0.324 \pm 0.082$ & $-9.3 \pm 1.2$ \\
\hline FBS & Medium & $88.8 \pm 5.2$ & $8.7 \pm 0.7$ & $0170 \pm 0.001$ & $-7 \pm 0.2$ \\
\hline
\end{tabular}

a Based on the particle number distribution; ${ }^{*} \mathrm{TiO}_{2} \mathrm{P} 25 \mathrm{NPs}$ showed a high sedimentation rate. The measurement thus mainly represents the stable fraction of NPs, which did not sediment during the measurement procedure.

\subsection{Direct Effects of NPs on Cell Viability}

To distinguish the direct and indirect effect of selected NPs on neuronal and microglial cell lines, we first determined the direct toxicity of NPs on each cell line separately. To adhere to the co-culture exposure protocols, the viability was assessed after $24 \mathrm{~h}$ for microglial cells and after $48 \mathrm{~h}$ for differentiated CAD cells.

There was no decrease in cell viability or significant increase in dead cells (Figure 1) and no changes in cell morphology for neither CAD not microglial cell line (Figures S4-S9). MGH NPs caused a small, concentration dependent increase in cell number in microglial cells (Figure 1B), and a similar, but not significant increase in CAD neuronal cells (Figure 1E). Microglial cells showed a high internalization rate, as indicated by optically dense areas observable inside the cells, especially at higher concentrations of PAA and $\mathrm{TiO}_{2}$ P25 NPs (Figures S4 and S6).

\subsection{NP Internalization (TEM)}

The internalization of NPs was assessed using TEM following incubation with $25 \mu \mathrm{g} / \mathrm{mL}$ of NPs. All three types of NPs were internalized in both cell lines and were found in membrane bound vesicles undergoing the endolysosomal trafficking route (Figure 2). NPs were observed in endosomes, lysosomes as well as amphysome or possibly autophagosomes, suggesting that the presence of NPs did not significantly interfere with the normal intracellular vesicle trafficking. No NPs were found free in the cytosol or associated with other organelles. Based on the number of observed vesicles on TEM samples, microglial cells showed considerably higher uptake rate compared to CAD neuronal cells (results not shown), which is also consistent with the observations with phase contrast microscopy (Figures S4-S9) and literature [15,16]. 
A Microglia PAA

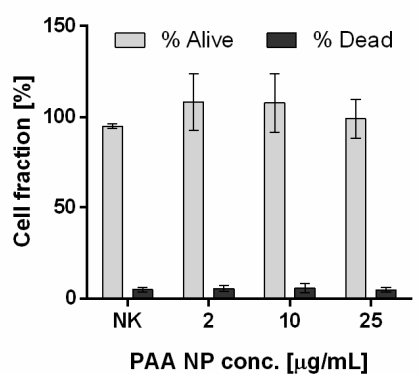

D CAD PAA

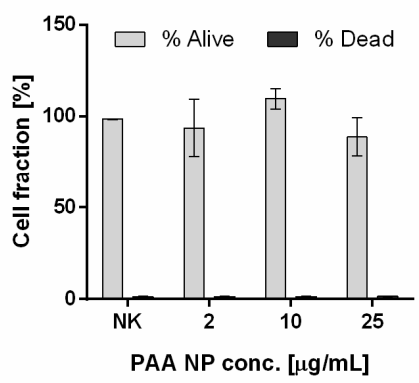

B Microglia maghemite

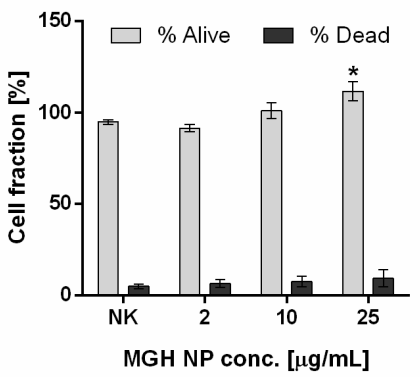

E CAD maghemite

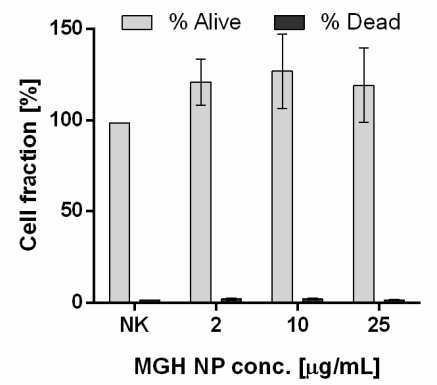

C Microglia $\mathrm{TiO}_{2} \mathrm{P} 25$

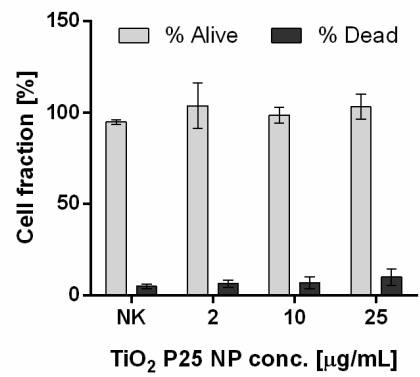

F $\mathrm{CAD} \mathrm{TiO} 2 \mathrm{P} 25$

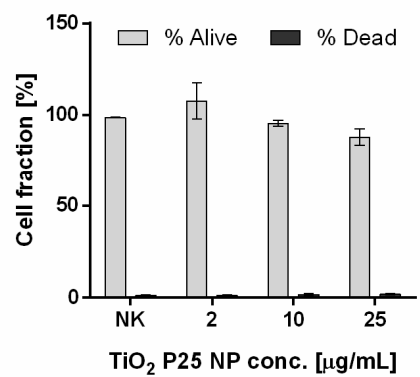

Figure 1. Viability of (A-C) mouse microglial cells following $24 \mathrm{~h}$ incubation and (D-F) mouse neuronal CAD cells following $48 \mathrm{~h}$ incubation with increasing concentration of $(\mathbf{A}, \mathbf{D})$ biomedical polyacrylic acid (PAA) coated cobalt ferrite NPs, (B,E) uncoated maghemite (MGH) NPs and (C,F) industrial $\mathrm{TiO}_{2}$ P25 NPs. Viability was determined with Hoechst/PI differential staining. Mean and standard error are shown for three independent experiments performed in duplicates. Statistical significance is displayed as: $\mathrm{ns}(p>0.05) ;{ }^{*} p \leq 0.05$.

PAA
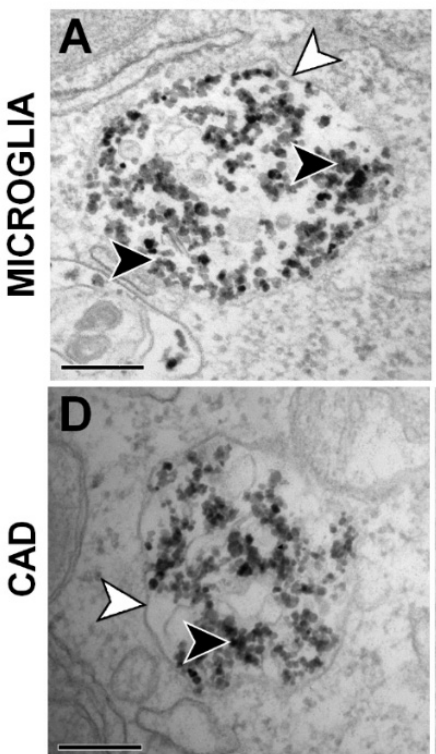

MGH
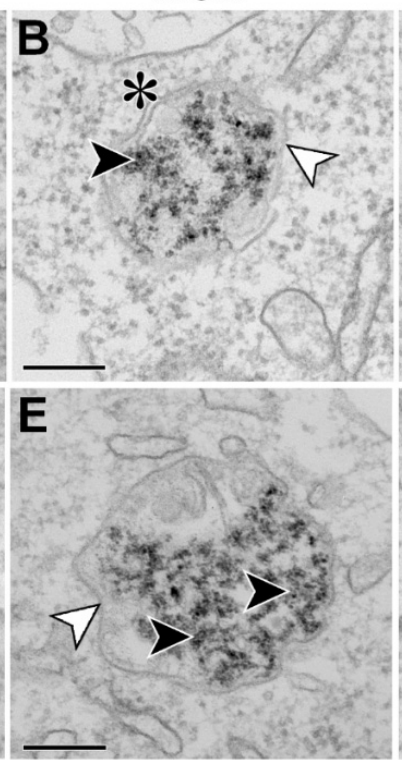

\section{$\mathrm{TiO}_{2} \mathrm{P} 25$}
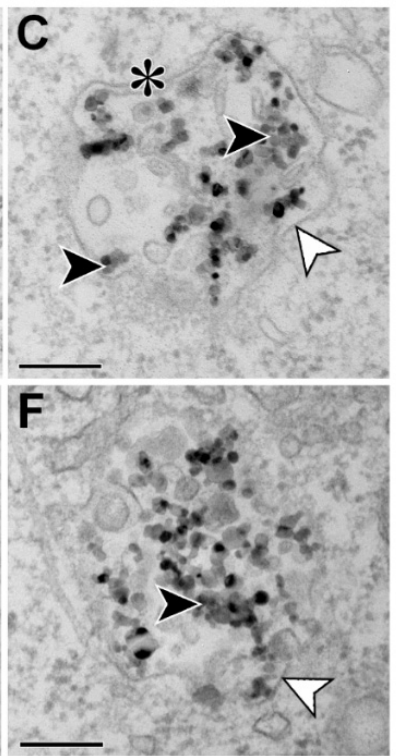

Figure 2. Confirmation of internalization of $(\mathbf{A}, \mathbf{D})$ biomedical polyacrylic acid (PAA) coated cobalt ferrite NPs, (B,E) uncoated maghemite $(\mathrm{MGH}) \mathrm{NPs}$ and $(\mathbf{C}, \mathbf{F})$ industrial $\mathrm{TiO}_{2}$ P25 NPs in mouse microglial cells (A-C) following $24 \mathrm{~h}$ incubation and differentiated CAD cells (D-F) following $48 \mathrm{~h}$ incubation with $25 \mu \mathrm{g} / \mathrm{mL}$ of NPs. NPs are denoted by full arrowheads and vesicular membranes by empty arrowheads. Double membranes, typical of amphisomes or autophagosomes, are denoted by asterisks. Scale bars correspond to $200 \mathrm{~nm}$. 


\subsection{NP Induced Changes in Cell Stress and Secretion of Stress and Signaling Molecules}

Interactions of microglial cells with NPs can also induce cell stress independent of cell death or decrease in cell viability. Such changes occur on a molecular level and through changes in cell signaling and can result in formation of ROS, NO or secretion of different signaling molecules, such as cytokines. These molecules can then independently of NPs affect neural cells. ROS and cytokine secretion were thus determined for microglial cells incubated with increasing concentrations of selected NPs.

\subsubsection{Activation of Cell Stress Response}

Microglial activation of NF- $\mathrm{kB}$, a central transcription factor in cell stress and immune responses, plays an important role in the release of ROS and pro-inflammatory cytokines that can cause secondary neurotoxicity [33]. Due to the quick dynamics of NF- $\mathrm{kB}$ activation, an incubation timeline was performed to observe NF- $\mathrm{kB}$ activation dynamics through changes in phosphorylation following $30 \mathrm{~min}, 1 \mathrm{~h}, 3 \mathrm{~h}, 6 \mathrm{~h}$ and $24 \mathrm{~h}$ incubation with $25 \mu \mathrm{g} / \mathrm{mL}$ of NPs. However, no significant changes were observed on the levels of phosphorylated NF-kB protein for either NP type (Figure 3A).
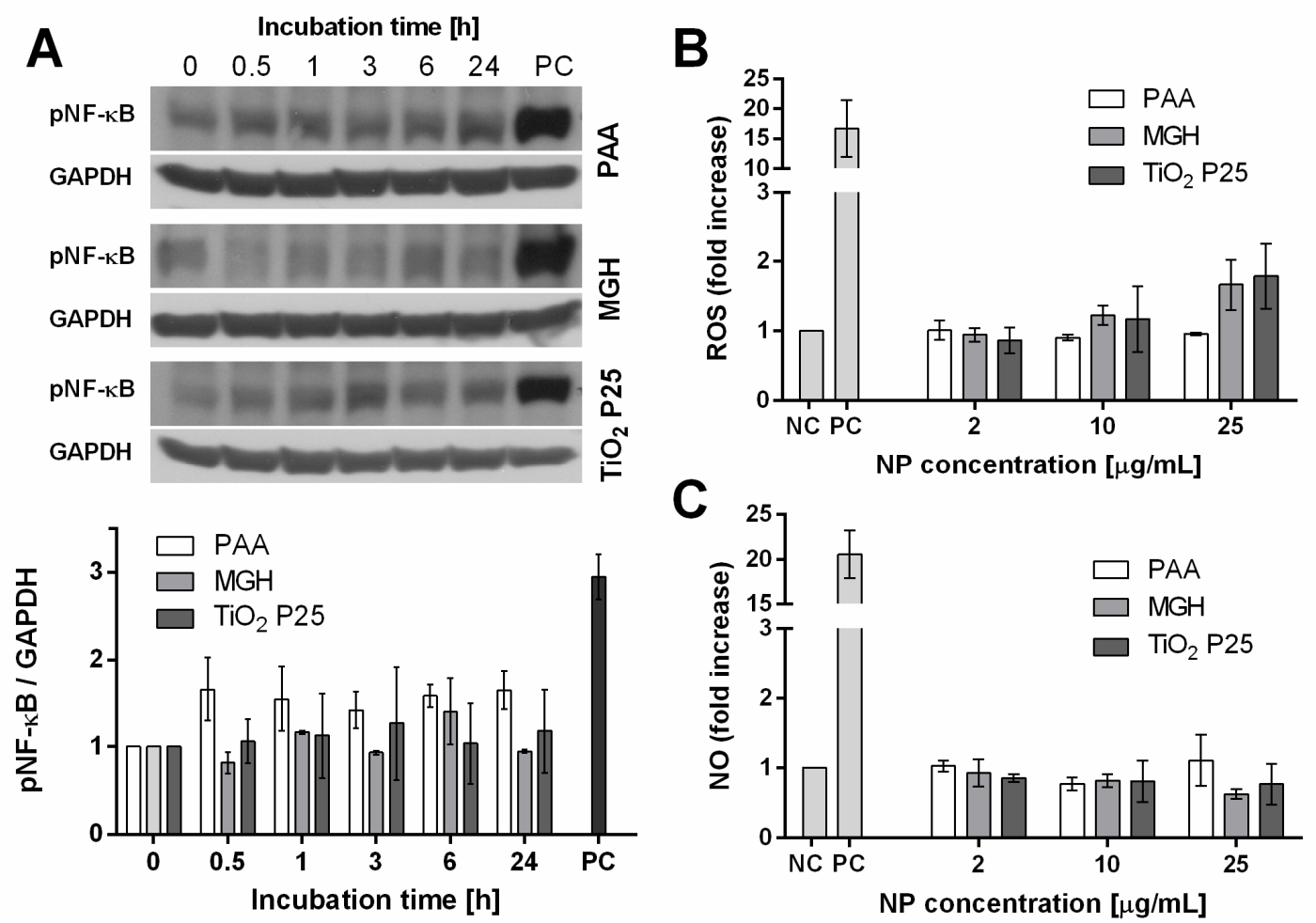

Figure 3. Cell stress response of microglial cells induced by $24 \mathrm{~h}$ incubation with increasing concentration of biomedical polyacrylic acid (PAA) coated cobalt ferrite NPs, uncoated maghemite (MGH) NPs and industrial $\mathrm{TiO}_{2} \mathrm{P} 25 \mathrm{NPs}$ in mouse microglial cells. (A) NF- $\mathrm{kB}$ activation was determined at different time points following incubation with $25 \mu \mathrm{g} / \mathrm{mL}$ NPs. $15 \mathrm{~min}$ incubation with $0.1 \mathrm{mM} \mathrm{H}_{2} \mathrm{O}_{2}$ was used as the positive control (PC). Mean and standard error are shown for two independent experiments. Representative blots are shown on top. (B) ROS were determined with CM- $\mathrm{H}_{2}$ DCFH-DA assay and normalized for cell number determined by Hoechst 33342 staining. $2 \mathrm{mM} \mathrm{H}_{2} \mathrm{O}_{2}$ was used as PC. (C) NO measurements were performed with Griess reagent. $5 \mathrm{ng} / \mathrm{mL}$ mouse recombinant IFN $\gamma$ was used as PC. For $(\mathbf{B}, \mathbf{C})$, mean and standard error are shown for three independent experiments performed in triplicates. No statistical differences were detected using One-way ANOVA.

\subsubsection{Generation of ROS and NO}

Mouse microglial cells were incubated with increasing concentrations of selected NPs for $24 \mathrm{~h}$ and analyzed for increase in generation of ROS and NO. Only the highest tested $(25 \mu \mathrm{g} / \mathrm{mL})$ concentrations 
of MGH and $\mathrm{TiO}_{2}$ P25 NPs induced a (not statistically significant) two-fold increase in ROS in a concentration dependent manner, while the lowest, physiologically achievable concentration $(2 \mu \mathrm{g} / \mathrm{mL})$ had no measurable effects (Figure 3B). PAA NPs had no effect on oxidative stress of microglial cells. On the other hand, none of the chosen NPs increased the secretion of NO following $24 \mathrm{~h}$ incubation even at the highest used concentration (Figure 3C).

\subsubsection{Cytokine Secretion}

Microglial cells were analysed for secretion of TNF $\alpha$, IL- 6 and IL-1 $\beta$, which are the main proinflammatory cytokines secreted from microglial cells and are reported to cause neurotoxicity and chronic inflammatory diseases [19]. There was a minor concentration dependent increase in TNF $\alpha$ secretion following incubation with PAA NPs, while there was no increase in TNF $\alpha$ for $\mathrm{MGH}$ and $\mathrm{TiO}_{2}$ P25 NPs and no change in secretion of IL- 6 . There was also no increase in IL-1 $\beta$ secretion, indicating there was no inflammasome activation at $25 \mu \mathrm{g} / \mathrm{mL}$ (Figure 4).
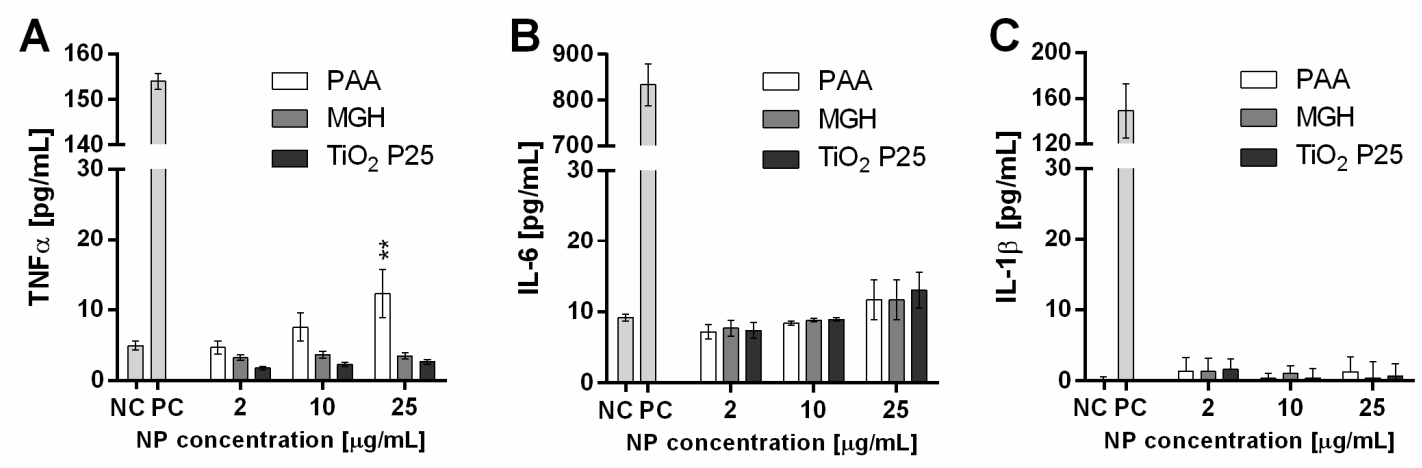

Figure 4. Secretion of (A) TNF $\alpha$, (B) IL-6 and (C) IL-1 $\beta$ cytokines following incubation with increasing concentration of biomedical polyacrylic acid (PAA) coated cobalt ferrite NPs, industrial $\mathrm{TiO}_{2} \mathrm{P}_{2} 5 \mathrm{NPs}$ and uncoated maghemite (MGH) NPs in mouse microglial cells as determined with ELISA. For TNF $\alpha$ and IL-6, $100 \mathrm{ng} / \mathrm{mL}$ LPS was used as a positive control (PC). For IL-1 $\beta$, cells were primed with $100 \mathrm{ng} / \mathrm{mL}$ LPS for $6 \mathrm{~h}$ before exposure and $200 \mu \mathrm{g} / \mathrm{mL}$ crystalline $\mathrm{SiO}_{2} \mathrm{NPs}_{\text {sere }}$ used as PC. Mean and standard error are shown for three independent experiments performed in three technical repeats. Statistical significance is displayed as: $\mathrm{ns}(p>0.05) ;{ }^{* *} p \leq 0.01$.

\subsection{Effects of Secreted Stress Mediators on Viability of CAD Neuronal Cells}

To determine the indirect effects of NP exposure on neuronal CAD cells, co-culture experiments with NP exposed microglial cells were performed. For studies of indirect toxicity, we utilized a co-culture model using a transwell system, which enabled simultaneous diffusion of soluble factors thus avoiding the loss of molecules with short half-life, such as ROS or NO, and still analyze each cell line separately. Unfortunately, in this manner we could not asses any effects resulting from direct cell-cell contact, however, due to a significantly shorter generation time of microglial cells compared to differentiated neuronal CAD cells (microglial cells would have overgrown the CAD neuronal cells), direct co-culture would be difficult to perform using the selected cell models.

The experiments showed that co-culture of differentiated CAD cells with microglial cells induced a slight, non-significant increase in CAD cell number, which was not observed when cells were grown with non-differentiated CAD cells in transwell inserts. Incubation of microglial cells with $25 \mu \mathrm{g} / \mathrm{mL}$ $\mathrm{TiO}_{2}$ P25 NPs augmented this effect, while incubation with MGH NPs reduced (not significantly) the observed increase. There was no increase in the fractions of dead cells (Figure 5A). Also, there were no significant changes on cell morphology $48 \mathrm{~h}$ after initial exposure (Figure S10).

Since we observed a small effect of microglial response to NP incubation on neuronal cells in co-culture despite the lack of any significant changes in secretion of the measured signaling mediators, we assessed the changes in the total secreted proteins from NP incubated microglial cells. Microglial 
cells in FBS free medium were incubated with $25 \mu \mathrm{g} / \mathrm{mL} \mathrm{NPs} \mathrm{for} 24 \mathrm{~h}$ and the obtained conditioned medium was assessed for the concentration of secreted proteins (Figure 5B) and resolved with SDS-page (Figure S11) to observe any significant changes in quantity of certain protein bands. Incubation with MGH NPs significantly reduced the amount of secreted proteins, while protein secretion from cells incubated with PAA and $\mathrm{TiO}_{2}$ P25 NPs remained approximately the same. Only minor changes in specific band intensities can be observed on stained gels (Figure S11), however a more detailed analysis should be performed to determine the significance of such changes.
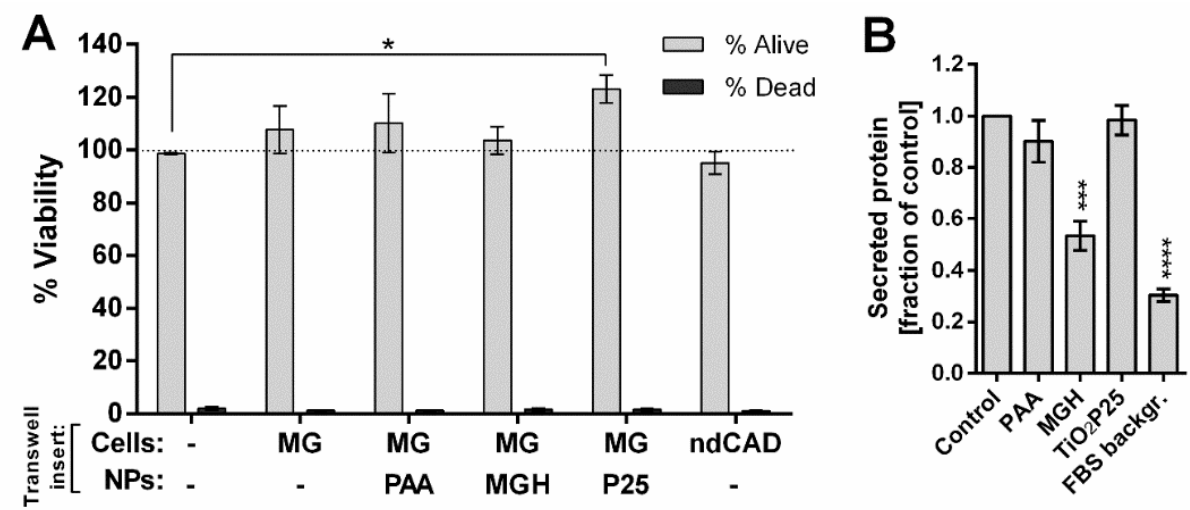

Figure 5. The indirect effects of NPs on mouse neural CAD cells. (A) Differentiated CAD cells were incubated with NP exposed microglial cells (MG) for $24 \mathrm{~h}$ by using the transwell system. Following incubation with $25 \mu \mathrm{g} / \mathrm{mL}$ NPs, transwell inserts were removed and CAD cells were left to rest for another $24 \mathrm{~h}$ in the same conditioned medium before cell viability was assessed microscopically. (B) Quantification of proteins secreted by mouse microglial cells incubated with $25 \mu \mathrm{g} / \mathrm{mL}$ NPs for $24 \mathrm{~h}$ in FBS free medium. Mean and standard error are shown for three independent experiments. Statistical significance is displayed as follows: $\mathrm{ns}(p>0.05) ;{ }^{*} p \leq 0.05 ;{ }^{* * *} p \leq 0.001,{ }^{* * * *} p \leq 0.0001$.

\section{Discussion}

Although the rate of NP translocation into the brain is relatively low due to effective protective barriers (blood-brain barrier, intranasal mucosa), several studies have shown that environmental and therapeutic NPs can still reach the central nervous system, especially in cases of age-related or pathological damage to the blood brain-barrier. $\mathrm{TiO}_{2}$ and iron oxide NPs were detected in mice and rat brain following different routes of administration including inhalation [34-39], which is most relevant route for environmental NPs, although other studies failed to detect these NPs in the brain $[40,41]$. Combustion derived magnetite NPs were also found in the brain of Alzheimer patients at the concentration of $0.2-12 \mu \mathrm{g} / \mathrm{g}$ dry brain tissue [8]. Due to the immunologically restricted status of the brain tissue and a lack of effective mechanism for particle removal, such particles tend to accumulate for prolonged time intervals [42]. This is especially problematic for non-degradable NPs, which can lead to sustained microglial activation and chronic inflammation [33].

Microglia play a double role in toxic insults in the brain: on one hand, acting as phagocytes they remove damaged cells and particulate matter, such as NPs or fibrils, while on the other hand, their activation and secretion of neurotoxic and signaling mediators, such as ROS or cytokines, can damage the neuronal cells, thus contributing to the inflammation and progression of potential neurodegeneration $[17,19,33]$. This is also reflected in contradicting results obtained in different co-culture studies, where the indirect effects are attributed to the ability of different industrial NPs to activate microglial cells for increased uptake or for secretion of toxic mediators [24-27].

In this study, we analyzed the ability of low, physiologically achievable concentrations of three types of NPs to activate mouse microglial cells to induce indirect effects on differentiated mouse neuronal cells in vitro. The direct toxicity studies showed that the used NP concentrations $(2-25 \mu \mathrm{g} / \mathrm{mL})$ had no considerable effect on the number of viable cells in either cell line, although there was a slight increase in cell number following incubation with MGH NPs in both cell lines, which could be 
attributed to the presence of iron ions. A similar tendency was observed also in BV2 microglial cells incubated with iron oxide NPs, depending on their crystal structure [35]. Additionally, iron oxide NPs increased the proliferation and migration of mesenchymal stem cells $[43,44]$, proposing the interference of released iron ions with ROS generation and cell cycle progression as the underlying mechanism. Iron is an important cofactor in several enzymes, including enzymes involved in myelin production and maintenance and mitochondrial oxidative metabolism. As such it plays an important role in cell proliferation, metabolism and differentiation $[45,46]$. While lower increase in iron concentration might thus have a stimulatory effect on cell proliferation, as observed also in our study, higher concentrations still induce toxicity and possibly neurodegeneration $[47,48]$. None of the herein tested NPs induced direct membrane damage (Figure 1).

TEM analysis showed internalization of these NPs in both cell lines (Figure 2). Due to the size of NPs and NP aggregates, internalization probably occurred through a non-phagocytic pathway, such as macropinocytosis or clathrin-mediated endocytosis, as observed previously [29,30,49]. Despite significant internalization of NPs in microglial cells, there was no activation of transcription factor NF- $\mathrm{kB}$ (Figure 3A) and a low (for PAA NPs) or no increase (for $\mathrm{MGH}$ and $\mathrm{TiO}_{2} \mathrm{P}_{2} 5 \mathrm{NPs}$ ) in cytokine secretion (Figure 4). On the other hand, $\mathrm{MGH}$ and $\mathrm{TiO}_{2} \mathrm{P} 25 \mathrm{NPs}$ induced a small, not-significant concentration dependent increase in ROS, which could be a result of mitochondrial stress or oxidative burst [50]. However, since this was not reflected in NF-kB activation, ROS were most probably generated through the iron-catalyzed Fenton reaction in case of MHG NPs, [51,52] or generated through photocatalytic surface reactivity of $\mathrm{TiO}_{2} \mathrm{P} 25 \mathrm{NPs}$ [53].

To assess the effect of NPs on communication between microglial and neuronal cells and possible indirect toxicity of NPs, co-culture experiments were performed. These experiments showed that co-culture of differentiated CAD cells with microglial cells induced a slight, not significant increase in CAD cell number. This increase was not observed when cells were grown with non-differentiated CAD cells in transwell inserts, indicating the increase is most probably caused by signaling/growth mediators constantly secreted by microglial cells and is not a consequence of increased nutrient consumption.

Incubation of microglial cells with $25 \mu \mathrm{g} / \mathrm{mL} \mathrm{TiO}_{2} \mathrm{P} 25 \mathrm{NPs}$ slightly augmented this microglia-induced increase in CAD cell number, which was not observed previously for $\mathrm{TiO}_{2} \mathrm{NPs}$. Hsiao et al. [25] showed that incubation of murine BV2 microglial cells with $100 \mu \mathrm{g} / \mathrm{mL} \mathrm{TiO}_{2} \mathrm{NPs}(6 \mathrm{~nm}$ crystal size, $100 \%$ anatase) had no effect on viability of differentiated mouse N2a neuronal cells in a transwell co-culture system. As they also observed no increase in neuronal cell number following co-culture with BV2 microglial cells, the observed increase in neuronal cell number observed in our study and the underlying cell-cell communication might be cell type/cell system specific.

On the other hand, incubation with MGH NPs marginally reduced this microglia-induced increase in CAD cell number. Interestingly, in monoculture experiments, MGH NPs slightly increased the number of CAD cells, while incubation with $\mathrm{TiO}_{2} \mathrm{P} 25 \mathrm{NPs}$ reduced their number, clearly indicating that the observed changes on CAD cells in co-culture experiment are a consequence of microglial secreted mediators and not an effect of possible NPs (or iron ions in case of MGH NPs) translocating through the porous membrane to the lower transwell chamber. Since CAD cells were not fully differentiated (the cells still showed a low level of cell proliferation), we assume that the mediators secreted by microglial cells most probably reduced or averted CAD cell differentiation, thus increasing cell proliferation. Moreover, it was demonstrated that low levels of ROS could stimulate proliferation in certain cell types [54], which could also be a possible mechanism behind the increase in neuronal cell number observed following CAD exposure to $\mathrm{TiO}_{2}$ P25 stimulated microglial cells, since the later exhibited a 2-fold increase in ROS production at $25 \mu \mathrm{g} / \mathrm{mL} \mathrm{TiO}_{2}$ P25 NPs (Figure 3B). Interestingly, the responses of CAD cells to MGH incubated microglial cells correspond to the observed decrease in secretion of soluble protein mediators from microglial cells. The decrease in protein secretion might have occurred through inhibition of the secretory lysosomal pathway, as was observed in a previous study, where $\mathrm{Wu}$ and coworkers showed that iron oxide NPs reduced LPS induced secretion of IL-1 $\beta$ (but not TNF $\alpha$ ) through impairment of lysosomal degradation and increase in lysosomal permeability [55]. Similarly, Britton 
and coworkers showed that iron affects the secretion of more than 60 proteins in cultured human adipocytes, including several signaling proteins [56]. Based on the changes in secretion, they propose that iron might have a specific effect on proteins secreted via the classic protein secretion pathway. In this way, MGH NPs and iron ions released from MGH NPs might have reduced the amount of secreted mediators from microglial cell, resulting in the lack of increase in number of CAD cells induced by co-incubation with microglial cells (Figure 5).

To sum up, PAA magnetic NPs, designed for biotechnological and biomedical applications [29,30], expectedly showed the least effects on all analysed cell stress parameters, despite being internalized in the highest amounts in both cell lines. PAA NPs only induces a concentration dependent increase in ROS and TNF $\alpha$ cytokine secretion in microglial cells and no changes were detected on viability of CAD cells in co-culture system. Uncoated MGH NPs, used as an example of environmental NPs, induced a small, concentration dependent increase in viable cells in both cell lines, and a concentration dependent increase in ROS in microglial cells. Despite that, there was a lack of an increase in CAD cell number in co-culture experiments, most probably mediated through MGH induced reduction in secretion of protein mediators from microglial cells. $\mathrm{TiO}_{2} \mathrm{P} 25 \mathrm{NPs}$ only induced a concentration dependent increase in ROS, however, an increase in CAD cell number compared to non-incubated CAD cells in co-culture system was observed. Identification of secreted proteins, which would allow us to determine the differentially secreted signaling mediators, as well as changes in gene and protein expression in both cell lines should be performed to better explain and evaluate the observed changes.

Taken together, this study analysed the effect of lower concentration of NPs, which could gain access in central nervous system. We demonstrate that in short time period of $24 \mathrm{~h}$, low concentrations of NPs induce relatively low levels of cell stress responses, and small changes in secretion of protein stress mediators. However, prolonged exposure to NPs and possible accumulation of NPs in cells, as observed in this study even after such short exposure period, could have a cumulative effect exciding the effects observed in this study. Indirect toxicity of NPs is an important and not adequately assessed mechanism of NP toxicity, since it not only affects cells locally (on the exposure site), but through secretion of signaling mediators, can also affect cells that do not come in direct contact with NPs. This is especially important for central nervous tissue due to its restricted repair mechanisms and high susceptibility to inflammation [57]. Moreover, mediators secreted from activated microglial cells can damage neuronal cells, and the damaged tissue further activates microglial cells, leading into a positive activation loop [33]. It is also important to note that NPs can affect the cells through released ions and other impurities, which can, similarly to secreted mediators, translocate the barriers and disrupt the tissue homeostasis away from exposure/accumulation sites. More studies, including long-term studies on relevant co-culture neural models are thus needed to better understand the risks of environmental NP exposure in our daily lives.

\section{Materials and Methods}

\subsection{Nanoparticles}

$\mathrm{TiO}_{2}$ P25 NPs were obtained from Sigma-Aldrich (St. Louis, MO, USA), the powder was temperature sterilized and dispersed in ultrapure water. Polyacrylic acid (PAA) coated cobalt ferrite $\left(\mathrm{CoFe}_{2} \mathrm{O}_{4}\right) \mathrm{NPs}$ were prepared as described previously [29]. Uncoated maghemite (MGH) were prepared by precipitation from an aquatic solution of $1 \mathrm{M} \mathrm{Fe}\left(\mathrm{NO}_{3}\right)_{3}$ and $1 \mathrm{M} \mathrm{FeCl}_{2}$ in $90^{\circ} \mathrm{C}$ heated $1 \mathrm{M} \mathrm{NaOH}$ under vigorous steering for $30 \mathrm{~min}$. The obtained particles were sedimented with a magnet and washed 3 times with $\mathrm{dH}_{2} \mathrm{O}$, followed by addition of $2 \mathrm{M} \mathrm{HNO}_{3}$ and mixing for $10 \mathrm{~min}$. The acid was removed by sedimentations, $0.3 \mathrm{M} \mathrm{Fe}\left(\mathrm{NO}_{3}\right)_{3}$ was added and heated to $95^{\circ} \mathrm{C}$ for $30 \mathrm{~min}$. After cooling the suspension to room temperature and sedimentation, the supernatant was replaced with $\mathrm{dH}_{2} \mathrm{O}$, mixed and centrifuged for $5 \mathrm{~min}$ at $1000 \mathrm{~g}$. The supernatant was collected and adjusted to $\mathrm{pH} 2$ with 2 $\mathrm{M} \mathrm{NaOH}$ to obtain a stable suspension. 
For size characterization and Zeta potential ( $\xi$-potential) measurements of all NPs, we used Malvern Zetasizer Nano ZS (Malvern Industries, Malvern, UK). Zeta potential, hydrodynamic diameter, Z-average size and polydispersity index (PDI) values were obtained. Characterization was performed in distilled water and in DMEM cell culture media with $10 \%$ FBS. No presence of endotoxins $(<0.5 \mathrm{EU} / \mathrm{mL})$ was found in all NP suspensions (PYROGENT ${ }^{\mathrm{TM}}$ Plus Gel Clot LAL Assays, Lonza Group Ltd., Basel, Switzerland).

\subsection{Cell Culturing, Cell Differentiation and Experiment Design}

All experiments were performed on immortalized mouse neural cells. Immortalized microglial cell line was a generous gift from Katherine Fitzgerald and Douglas Golenbock (Department of Infectious Diseases and Immunology, University of Massachusetts Medical School, Worcester, MA, USA), and CAD cell line from Dona M. Chikaraishi (Department of Neurobiology, Duke University Medical Center, Durham, NC, USA). The preparation of immortalized mouse microglial cells from wild type (C57BL/6) mice was described previously [58]. Microglial cells were grown in DMEM cell culture medium (Gibco) supplemented with 10\% FBS (Sigma).

Immortalized mouse neuronal cell line CAD, a variant of Cath.a cell line capable of differentiation [59], was grown in OptiMEM supplemented with 10\% FBS and adjusted to DMEM supplemented with $10 \%$ FBS in order to perform co-culture experiments. CAD cells were differentiated by growing them in differentiation media (DMEM supplemented with $2 \%$ FBS and $10 \mu \mathrm{M}$ retinoic acid; Sigma) for 5 days. All NP incubations were performed in DMEM supplemented with $10 \%$ FBS. Both cell lines were grown, differentiated and exposed to NPs in a cell culture incubator in a humidified $5 \% \mathrm{CO}_{2}$ atmosphere at $37^{\circ} \mathrm{C}$.

\subsection{Exposure and Co-Culture Protocols}

All exposure and non-contact co-culture experiments were performed on microglial cells and differentiated CAD neuronal cells. In co-culture experiments with a transwell system (PET membrane bottom, pore size $0.4 \mu \mathrm{m}, 2 \times 10^{6}$ pores $/ \mathrm{cm}^{2}$ Sarstedt AG \& Co. KG, Nümbrecht, Germany), differentiated CAD cells were exposed to mouse microglial cells incubated with NPs for $24 \mathrm{~h}$. After this, transwell inserts with NP incubated microglial cells were removed and CAD were left another $24 \mathrm{~h}$ in the same conditioned medium containing secreted molecules and stress mediators to allow time for manifestation of any effects on cell viability or morphology (Figure 6). To obtain comparable results, each cell line in mono-culture experiments was incubated with the same incubation time as in co-culture experiments: microglial cells were incubated for $24 \mathrm{~h}$ and differentiated CAD for $48 \mathrm{~h}$.
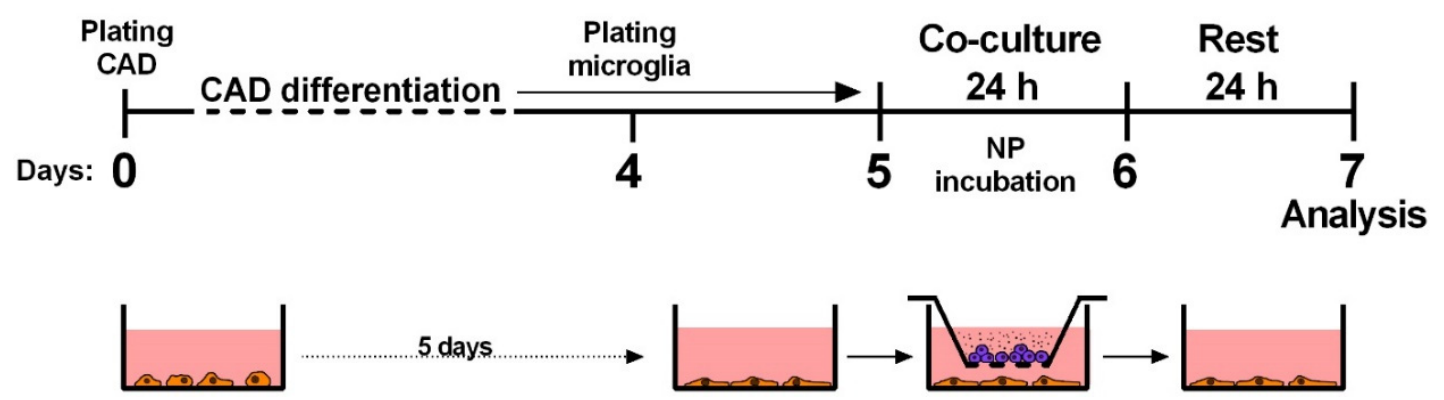

Figure 6. Schematic representation of the procedure for co-culture experiments. CAD cells were differentiated for 5 days, exposed to NP incubated microglial cells in a non-contact co-culture through a transwell system for $24 \mathrm{~h}$ and left another $24 \mathrm{~h}$ in the same conditioned medium before analysis.

\subsection{Cell Viability Assay}

Differential staining viability assay was performed as described previously [29]. Briefly, following NP exposure, cells were stained with $2 \mu \mathrm{g} / \mathrm{mL}$ Hoechst 33342 (Life Technologies, Carlsbad, CA, USA) to obtain the total cell number and with $0.15 \mathrm{mM}$ Propidium iodide (PI; Sigma-Aldrich) for $5 \mathrm{~min}$ to 
stain dead cells. Cells on obtained fluorescent images were counted using CellCounter software [60]. The number of viable cells $\left(N_{S}\right)$ was calculated by subtracting dead (PI positive) from all counted cells (Hoechst positive) for each sample. The percentage of cell viability (\% Viability) was determined as the ratio between the number of viable cells in each sample $\left(\mathrm{N}_{S}\right)$ and the number of all cells in the non-treated control $\left(\mathrm{N}_{0}\right)$ : \%Viability $=100 \times \mathrm{N}_{\mathrm{S}} / \mathrm{N}_{0}$.

\subsection{ROS Assay}

ROS levels were determined with CM- $\mathrm{H}_{2}$ DCFH-DA assay (Molecular Probes, Invitrogen, Carlsbad, CA, USA) as described previously [61]. Briefly, cells were incubated with $10 \mu \mathrm{M} \mathrm{CM}-\mathrm{H}_{2}$ DCFDA in DMEM FluoroBrite (Gibco, Thermo Fisher Scientific, Waltham, MA, USA) at $37^{\circ} \mathrm{C}$ for $45 \mathrm{~min}$. We used $0.1 \mathrm{mM} \mathrm{H}_{2} \mathrm{O}_{2}$ as a positive control. CM- $\mathrm{H}_{2} \mathrm{DCFH}$-DA fluorescence was measured using spectrofluorometer Tecan Infinite 200 (Tecan, Männedorf, Switzerland) and corrected for cell number as obtained with Hoechst 33342 staining. The results are presented as percentage and standard error compared to the negative control sample for three independent experiments in four replicates.

\subsection{NO Assay}

Release of NO following $24 \mathrm{~h}$ incubation with NPs was measured with modified Griess reagent (Sigma-Aldricht) following manufacturers instruction. Briefly, supernatants of NP incubated microglial cells were collected and $50 \mu \mathrm{L}$ of cell supernatant was mixed with $50 \mu \mathrm{L}$ of $0.04 \%$ Griess reagent solution and incubated for $15 \mathrm{~min}$ in the dark at room temperature. Mouse IFN- $\gamma$ recombinant protein ( $5 \mathrm{ng} / \mathrm{mL}$, eBioscience, San Diego, CA, USA) was used as a positive control. For NO quantification purposes standard curve was made from nitrite (Promega, Madison, WI, USA). Absorbance was measured at $570 \mathrm{~nm}$.

\subsection{ELISA}

For detection of mouse cytokines TNF $\alpha$, IL- 6 and IL-1 $\beta$ we used ELISA (Affymetrix eBioscience Inc., Atlanta, GA, USA) following manufacturers' instructions. $100 \mathrm{ng} / \mathrm{mL}$ LPS or $200 \mu \mathrm{g} / \mathrm{mL} \mathrm{SiO}_{2}$ NPs (NLRP3 Inflammasome Inducer, Invivogen, San Diego, CA, USA) were used as positive controls. For IL-1 $\beta$ detection, cells were primed with $100 \mathrm{ng} / \mathrm{mL}$ LPS for $6 \mathrm{~h}$ prior to incubation with NPs.

\subsection{Transmission Electron Microscopy}

Samples for TEM analysis were prepared as described previously [29]. Briefly, microglial cells were incubated with NPs for $24 \mathrm{~h}$ before fixation, while CAD cells were first differentiated for 5 days and incubated with NPs for $48 \mathrm{~h}$. Cells were fixed with a mixture of $4 \%(w / v)$ paraformaldehyde and $2 \%(v / v)$ glutaraldehyde in $0.1 \mathrm{M}$ cacodylate buffer, $\mathrm{pH} 7.4$, for $4 \mathrm{~h}$ at $4{ }^{\circ} \mathrm{C}$. Post-fixation was carried out in $1 \%$ osmium tetroxide in $0.1 \mathrm{M}$ cacodylate buffer for $2 \mathrm{~h}$. Ultra-thin sections examined with a CM100 TEM (Philips Electron Optics, Eindhoven, The Netherlands) for cell ultrastructure, and the analyses of NP uptake and aggregation.

\subsection{Western Blot}

For western blot analysis, cells were washed with ice cold PBS and lysed with $1 \times$ Sample loading buffer [63 mM Tris HCl pH 6.8, 2\% SDS, 10\% glycerol, 0.002\% bromphenol blue, 5\% 2-mercaptoethanol]. Protein concentration was measured with Pierce $660 \mathrm{~nm}$ Protein Assay Reagent (Thermo Fischer Scientific, Rockford, IL, USA) following the manufacturer's instructions. Calibrated samples were loaded into $12 \%$ polyacrylamide gel, run at constant $30 \mathrm{~mA}$ per gel and transferred to PVDF membranes Millipore (Billerica, MA, USA) using the Bio RAD Mini-PROTEAN Tetra Cell (Bio-Rad, Hercules, CA, USA) with constant $150 \mathrm{~V}$ for $60 \mathrm{~min}$.

We used primary antibodies against GAP-43 (clone 9-1E12) (\#MAB347, diluted 1:1000, Merck, Kenilworth, NJ, USA), Lamin B1 (A-11) (sc-377000, diluted 1:1000, Santa Cruz Biotechnologies, Dallas, TX, USA), p-NF-kB p65 (27.Ser 536) (sc-136548, diluted 1:500, Santa Cruz Biotechnologies) and GAPDH 
(14C10) (\#2118, diluted 1:1000, Cell Signaling Technologies, Danvers, MA, USA) as the loading control. Primary antibodies were followed by incubation with the appropriate HRP-conjugated secondary antibody (Bio-Rad). Bioluminescence was detected with Pierce ECL Western Blotting substrate (Thermo Fischer Scientific). Quantity-One 1-D Analysis Software (Bio-Rad) was used for densitometric analysis.

\subsection{Analysis of Secreted Proteins}

Changes in overall protein secretion were analysed by incubating the cells with $25 \mu \mathrm{g} / \mathrm{mL}$ NPs in FBS free medium for $24 \mathrm{~h}$. FBS background (FBS proteins remaining attached to the plastic following washing steps to remove FBS before incubation in FBS free medium) was obtained by incubating and washing an empty well with the same steps as the seeded wells. Conditioned medium was collected and centrifuge to remove detached cells and NPs. Supernatant was concentrated using Amicon Ultra- $0.5 \mathrm{~mL}$ Centrifugal Filters 10 kDa NMWL (Merck) and the appropriate amount of $6 \times$ Sample Loading Buffer was added. Protein concentration was measured using Pierce $660 \mathrm{~nm}$ Protein Assay Reagent following manufacturer's instructions. Samples were resolved on 4-12\% TruePAGE precast gels (Sigma-Aldricht) with constant $150 \mathrm{~V}$. The gel was stained with $0.1 \%$ silver nitrate solution and developed with $3 \%$ sodium carbonate or with Coomassie blue R-250 following manufacturer's instructions.

\subsection{Statistics}

Results are presented as mean and standard error. One-way analysis of variance (ANOVA) with Dunnett's correction for multiple comparisons was performed to test for statistical differences between the control and treated samples. Statistical analyses were carried out with GraphPad Prism v6 (GraphPad Prism Software, La Jolla, CA, USA). Statistical significance is displayed as follows: ns $(p>0.05) ;{ }^{*} p \leq 0.05 ;{ }^{* *} p \leq 0.01{ }^{* * *} p \leq 0.001{ }^{* * * *} p \leq 0.0001$.

Supplementary Materials: Supplementary materials can be found at http://www.mdpi.com/1422-0067/21/19/ 7030/s1.

Author Contributions: Conceptualization, J.L., M.P., I.H.-B.; methodology, J.L., V.B.B., P.V., I.H.-B.; investigation, J.L., L.B., P.S., V.B.B.; formal analysis, J.L., L.B., P.S., V.B.B.; resources, J.L., P.V., M.P., I.H.-B.; writing-original draft preparation, J.L.; visualization, J.L.; supervision, J.L., M.P.; funding acquisition, J.L., M.P., P.V. All authors have read and agreed to the published version of the manuscript.

Funding: This work was supported by the Slovenian Research Agency (http://www.arrs.si/en/) (research project No. Z4-8229, J7-7424, research core funding P1-0055), young researchers program (Young Researcher grant to P.S.), MRIC UL IP-0510 Infrastructure programs (FE, IBC BMCM) and COST action BIONECA (CA16122).

Acknowledgments: The authors would like to thank Klemen Strojan for preparation of maghemite nanoparticles and LAL test as well as Nada Pavlica Dubarič and Sabina Železnik for their technical assistance with TEM sample preparation. We are grateful to Kate Fitzgerald and Douglas Golenbock for immortalized microglial cell line and Dona M. Chikaraishi for CAD cell line.

Conflicts of Interest: The authors declare no conflict of interest. The funders had no role in the design of the study; in the collection, analyses, or interpretation of data; in the writing of the manuscript, or in the decision to publish the results.

\section{Abbreviations}

$\begin{array}{ll}\text { NP } & \text { nanoparticle } \\ \text { ROS } & \text { reactive oxygen species } \\ \text { NO } & \text { nitric oxide } \\ \text { LPS } & \text { lipopolysaccharide } \\ \text { PAA } & \text { polyacrylic acid } \\ \text { MGH } & \text { maghemite } \\ \text { PDI } & \text { polydispersity index } \\ \text { PI } & \text { propidium iodide } \\ \text { TEM } & \text { transmission electron microscopy } \\ \text { NF- } \mathrm{kB} \text { nuclear factor } \mathrm{kB}\end{array}$




\section{References}

1. McCall, M.J. Environmental, health and safety issues: Nanoparticles in the real world. Nat. Nano 2011, 6, 613-614. [CrossRef] [PubMed]

2. Calderón-Garcidueñas, L.; Reed, W.; Maronpot, R.R.; Henríquez-Roldán, C.; Delgado-Chavez, R.; Calderón-Garcidueñas, A.; Dragustinovis, I.; Franco-Lira, M.; Aragón-Flores, M.; Solt, A.C.; et al. Brain inflammation and Alzheimer's-like pathology in individuals exposed to severe air pollution. Toxicol. Pathol. 2004, 32, 650-658. [CrossRef] [PubMed]

3. Peters, A.; Wichmann, H.E.; Tuch, T.; Heinrich, J.; Heyder, J. Respiratory effects are associated with the number of ultrafine particles. Am. J. Respir. Crit. Care Med. 1997, 155, 1376-1383. [CrossRef] [PubMed]

4. Vinzents, P.S.; Møller, P.; Sørensen, M.; Knudsen, L.E.; Hertel, O.; Jensen, F.P.; Schibye, B.; Loft, S. Personal Exposure to Ultrafine Particles and Oxidative DNA Damage. Environ. Health Perspect. 2005, 113, 1485-1490. [CrossRef] [PubMed]

5. Heusinkveld, H.J.; Wahle, T.; Campbell, A.; Westerink, R.H.S.; Tran, L.; Johnston, H.; Stone, V.; Cassee, F.R.; Schins, R.P.F. Neurodegenerative and neurological disorders by small inhaled particles. Neurotoxicology 2016, 56, 94-106. [CrossRef]

6. Mushtaq, G.; Khan, J.A.; Joseph, E.; Kamal, M.A. Nanoparticles, Neurotoxicity and Neurodegenerative Diseases. Curr. Drug Metab. 2015, 16, 676-684. [CrossRef]

7. Plascencia-Villa, G.; Ponce, A.; Collingwood, J.F.; Arellano-Jiménez, M.J.; Zhu, X.; Rogers, J.T.; Betancourt, I.; José-Yacamán, M.; Perry, G. High-resolution analytical imaging and electron holography of magnetite particles in amyloid cores of Alzheimer's disease. Sci. Rep. 2016, 6, 24873. [CrossRef]

8. Maher, B.A.; Ahmed, I.A.M.; Karloukovski, V.; MacLaren, D.A.; Foulds, P.G.; Allsop, D.; Mann, D.M.A.; Torres-Jardón, R.; Calderon-Garciduenas, L. Magnetite pollution nanoparticles in the human brain. Proc. Natl. Acad. Sci. USA 2016, 113, 10797-10801. [CrossRef]

9. Win-Shwe, T.-T.; Fujimaki, H. Nanoparticles and neurotoxicity. Int. J. Mol. Sci. 2011, 12, 6267-6280. [CrossRef]

10. Unfried, K.; Albrecht, C.; Klotz, L.-O.; Mikecz, A.V.; Grether-Beck, S.; Schins, R.P.F. Cellular responses to nanoparticles: Target structures and mechanisms. Nanotoxicology 2007, 1, 52-71. [CrossRef]

11. Hussain, S.; Garantziotis, S.; Rodrigues-Lima, F.; Dupret, J.-M.; Baeza-Squiban, A.; Boland, S. Intracellular signal modulation by nanomaterials. Adv. Exp. Med. Biol. 2014, 811, 111-134. [CrossRef] [PubMed]

12. Khanna, P.; Ong, C.; Bay, B.H.; Baeg, G.H. Nanotoxicity: An Interplay of Oxidative Stress, Inflammation and Cell Death. Nanomaterials 2015, 5, 1163-1180. [CrossRef] [PubMed]

13. Bhabra, G.; Sood, A.; Fisher, B.; Cartwright, L.; Saunders, M.; Evans, W.H.; Surprenant, A.; Lopez-Castejon, G.; Mann, S.; Davis, S.A.; et al. Nanoparticles can cause DNA damage across a cellular barrier. Nat. Nanotechnol. 2009, 4, 876-883. [CrossRef]

14. Sood, A.; Salih, S.; Roh, D.; Lacharme-Lora, L.; Parry, M.; Hardiman, B.; Keehan, R.; Grummer, R.; Winterhager, E.; Gokhale, P.J.; et al. Signalling of DNA damage and cytokines across cell barriers exposed to nanoparticles depends on barrier thickness. Nat. Nanotechnol. 2011, 6, 824-833. [CrossRef] [PubMed]

15. Pickard, M.R.; Chari, D.M. Robust Uptake of Magnetic Nanoparticles (MNPs) by Central Nervous System (CNS) Microglia: Implications for Particle Uptake in Mixed Neural Cell Populations. Int. J. Mol. Sci. 2010, 11, 967-981. [CrossRef]

16. Pinkernelle, J.; Calatayud, P.; Goya, G.F.; Fansa, H.; Keilhoff, G. Magnetic nanoparticles in primary neural cell cultures are mainly taken up by microglia. BMC Neurosci. 2012, 13, 32. [CrossRef] [PubMed]

17. Combs, C.K.; Karlo, J.C.; Kao, S.C.; Landreth, G.E. beta-Amyloid stimulation of microglia and monocytes results in TNFalpha-dependent expression of inducible nitric oxide synthase and neuronal apoptosis. J. Neurosci. 2001, 21, 1179-1188. [CrossRef]

18. Kim, Y.S.; Joh, T.H. Microglia, major player in the brain inflammation: Their roles in the pathogenesis of Parkinson's disease. Exp. Mol. Med. 2006, 38, 333-347. [CrossRef]

19. Hafner-Bratkovič, I.; Benčina, M.; Fitzgerald, K.A.; Golenbock, D.; Jerala, R. NLRP3 inflammasome activation in macrophage cell lines by prion protein fibrils as the source of IL-1 $\beta$ and neuronal toxicity. Cell. Mol. Life Sci. 2012, 69, 4215-4228. [CrossRef]

20. Czajka, M.; Sawicki, K.; Sikorska, K.; Popek, S.; Kruszewski, M.; Kapka-Skrzypczak, L. Toxicity of titanium dioxide nanoparticles in central nervous system. Toxicol. In Vitro 2015, 29, 1042-1052. [CrossRef] 
21. Ge, D.; Du, Q.; Ran, B.; Liu, X.; Wang, X.; Ma, X.; Cheng, F.; Sun, B. The neurotoxicity induced by engineered nanomaterials. Int. J. Nanomed. 2019, 14, 4167-4186. [CrossRef] [PubMed]

22. Hutter, E.; Boridy, S.; Labrecque, S.; Lalancette-Hébert, M.; Kriz, J.; Winnik, F.M.; Maysinger, D. Microglial Response to Gold Nanoparticles. ACS Nano 2010, 4, 2595-2606. [CrossRef] [PubMed]

23. Long, T.C.; Saleh, N.; Tilton, R.D.; Lowry, G.V.; Veronesi, B. Titanium Dioxide (P25) Produces Reactive Oxygen Species in Immortalized Brain Microglia (BV2): Implications for Nanoparticle Neurotoxicity. Environ. Sci. Technol. 2006, 40, 4346-4352. [CrossRef] [PubMed]

24. Neubert, J.; Wagner, S.; Kiwit, J.; Bräuer, A.U.; Glumm, J. New findings about iron oxide nanoparticles and their different effects on murine primary brain cells. Int. J. Nanomed. 2015, 10, 2033-2049. [CrossRef]

25. Hsiao, I.-L.; Chang, C.-C.; Wu, C.-Y.; Hsieh, Y.-K.; Chuang, C.-Y.; Wang, C.-F.; Huang, Y.-J. Indirect effects of $\mathrm{TiO}_{2}$ nanoparticle on neuron-glial cell interactions. Chem. Biol. Interact. 2016, 254, 34-44. [CrossRef]

26. Hsiao, I.-L.; Hsieh, Y.-K.; Chuang, C.-Y.; Wang, C.-F.; Huang, Y.-J. Effects of silver nanoparticles on the interactions of neuron- and glia-like cells: Toxicity, uptake mechanisms, and lysosomal tracking. Environ. Toxicol. 2017, 32, 1742-1753. [CrossRef]

27. Xue, Y.; Wu, J.; Sun, J. Four types of inorganic nanoparticles stimulate the inflammatory reaction in brain microglia and damage neurons in vitro. Toxicol. Lett. 2012, 214, 91-98. [CrossRef]

28. Long, T.C.; Tajuba, J.; Sama, P.; Saleh, N.; Swartz, C.; Parker, J.; Hester, S.; Lowry, G.V.; Veronesi, B. Nanosize Titanium Dioxide Stimulates Reactive Oxygen Species in Brain Microglia and Damages Neurons in Vitro. Environ. Health Perspect. 2007, 115, 1631-1637. [CrossRef]

29. Bregar, V.B.; Lojk, J.; Šuštar, V.; Veranič, P.; Pavlin, M. Visualization of internalization of functionalized cobalt ferrite nanoparticles and their intracellular fate. Int. J. Nanomed. 2013, 8, 919-931. [CrossRef]

30. Lojk, J.; Bregar, V.B.; Rajh, M.; Miš, K.; Kreft, M.E.; Pirkmajer, S.; Veranič, P.; Pavlin, M. Cell type-specific response to high intracellular loading of polyacrylic acid-coated magnetic nanoparticles. Int. J. Nanomed. 2015, 10, 1449-1462. [CrossRef]

31. Pavlin, M.; Bregar, V.B. Stability of nanoparticle suspensions in different biologically relevant media. Gig. J. Nanomater. Biostruct. 2012, 7, 1389-1400.

32. Bickley, R.I.; Gonzalez-Carreno, T.; Lees, J.S.; Palmisano, L.; Tilley, R.J.D. A structural investigation of titanium dioxide photocatalysts. J. Solid State Chem. 1991, 92, 178-190. [CrossRef]

33. Block, M.L.; Zecca, L.; Hong, J.-S. Microglia-mediated neurotoxicity: Uncovering the molecular mechanisms. Nat. Rev. Neurosci. 2007, 8, 57-69. [CrossRef] [PubMed]

34. Disdier, C.; Chalansonnet, M.; Gagnaire, F.; Gaté, L.; Cosnier, F.; Devoy, J.; Saba, W.; Lund, A.K.; Brun, E.; Mabondzo, A. Brain Inflammation, Blood Brain Barrier dysfunction and Neuronal Synaptophysin Decrease after Inhalation Exposure to Titanium Dioxide Nano-aerosol in Aging Rats. Sci. Rep. 2017, 7, 12196. [CrossRef]

35. Wang, Y.; Wang, B.; Zhu, M.-T.; Li, M.; Wang, H.-J.; Wang, M.; Ouyang, H.; Chai, Z.-F.; Feng, W.-Y.; Zhao, Y.-L. Microglial activation, recruitment and phagocytosis as linked phenomena in ferric oxide nanoparticle exposure. Toxicol. Lett. 2011, 205, 26-37. [CrossRef]

36. Wang, B.; Feng, W.; Zhu, M.; Wang, Y.; Wang, M.; Gu, Y.; Ouyang, H.; Wang, H.; Li, M.; Zhao, Y.; et al. Neurotoxicity of low-dose repeatedly intranasal instillation of nano- and submicron-sized ferric oxide particles in mice. J. Nanopart. Res. 2009, 11, 41-53. [CrossRef]

37. Wang, J.; Chen, C.; Liu, Y.; Jiao, F.; Li, W.; Lao, F.; Li, Y.; Li, B.; Ge, C.; Zhou, G.; et al. Potential neurological lesion after nasal instillation of $\mathrm{TiO}_{2}$ nanoparticles in the anatase and rutile crystal phases. Toxicol. Lett. 2008, 183, 72-80. [CrossRef]

38. Wang, B.; Wang, Q.S.; Chen, H.; Zhou, X.; Wang, H.; Wang, H.; Zhang, J.; Feng, W. Size-Dependent Translocation Pattern, Chemical and Biological Transformation of Nano- and Submicron-Sized Ferric Oxide Particles in the Central Nervous System. J. Nanosci. Nanotechnol. 2016, 16, 5553-5561. [CrossRef]

39. Pujalté, I.; Dieme, D.; Haddad, S.; Serventi, A.M.; Bouchard, M. Toxicokinetics of titanium dioxide $\left(\mathrm{TiO}_{2}\right)$ nanoparticles after inhalation in rats. Toxicol. Lett. 2017, 265, 77-85. [CrossRef]

40. Gaté, L.; Disdier, C.; Cosnier, F.; Gagnaire, F.; Devoy, J.; Saba, W.; Brun, E.; Chalansonnet, M.; Mabondzo, A. Biopersistence and translocation to extrapulmonary organs of titanium dioxide nanoparticles after subacute inhalation exposure to aerosol in adult and elderly rats. Toxicol. Lett. 2017, 265, 61-69. [CrossRef]

41. Shinohara, N.; Danno, N.; Ichinose, T.; Sasaki, T.; Fukui, H.; Honda, K.; Gamo, M. Tissue distribution and clearance of intravenously administered titanium dioxide $\left(\mathrm{TiO}_{2}\right)$ nanoparticles. Nanotoxicology 2014, 8 , 132-141. [CrossRef] [PubMed] 
42. Hu, Y.-L.; Gao, J.-Q. Potential neurotoxicity of nanoparticles. Int. J. Pharm. 2010, 394, 115-121. [CrossRef] [PubMed]

43. Huang, D.-M.; Hsiao, J.-K.; Chen, Y.-C.; Chien, L.-Y.; Yao, M.; Chen, Y.-K.; Ko, B.-S.; Hsu, S.-C.; Tai, L.-A.; Cheng, H.-Y.; et al. The promotion of human mesenchymal stem cell proliferation by superparamagnetic iron oxide nanoparticles. Biomaterials 2009, 30, 3645-3651. [CrossRef] [PubMed]

44. Li, X.; Wei, Z.; Lv, H.; Wu, L.; Cui, Y.; Yao, H.; Li, J.; Zhang, H.; Yang, B.; Jiang, J. Iron oxide nanoparticles promote the migration of mesenchymal stem cells to injury sites. Int. J. Nanomed. 2019, 14, 573-589. [CrossRef]

45. Piñero, D.J.; Li, N.Q.; Connor, J.R.; Beard, J.L. Variations in dietary iron alter brain iron metabolism in developing rats. J. Nutr. 2000, 130, 254-263. [CrossRef]

46. Rosato-Siri, M.V.; Marziali, L.; Guitart, M.E.; Badaracco, M.E.; Puntel, M.; Pitossi, F.; Correale, J.; Pasquini, J.M. Iron Availability Compromises Not Only Oligodendrocytes but Also Astrocytes and Microglial Cells. Mol. Neurobiol. 2018, 55, 1068-1081. [CrossRef]

47. Zecca, L.; Youdim, M.B.H.; Riederer, P.; Connor, J.R.; Crichton, R.R. Iron, brain ageing and neurodegenerative disorders. Nat. Rev. Neurosci. 2004, 5, 863-873. [CrossRef]

48. Wang, L.; Yin, Y.-L.; Liu, X.-Z.; Shen, P.; Zheng, Y.-G.; Lan, X.-R.; Lu, C.-B.; Wang, J.-Z. Current understanding of metal ions in the pathogenesis of Alzheimer's disease. Transl. Neurodegener. 2020, 9, 10. [CrossRef]

49. Luther, E.M.; Petters, C.; Bulcke, F.; Kaltz, A.; Thiel, K.; Bickmeyer, U.; Dringen, R. Endocytotic uptake of iron oxide nanoparticles by cultured brain microglial cells. Acta Biomater. 2013, 9, 8454-8465. [CrossRef]

50. Manke, A.; Wang, L.; Rojanasakul, Y. Mechanisms of Nanoparticle-Induced Oxidative Stress and Toxicity. Available online: https://www.hindawi.com/journals/bmri/2013/942916/ (accessed on 18 August 2020).

51. Kehrer, J.P. The Haber-Weiss reaction and mechanisms of toxicity. Toxicology 2000, 149, 43-50. [CrossRef]

52. Wu, H.; Yin, J.-J.; Wamer, W.G.; Zeng, M.; Lo, Y.M. Reactive oxygen species-related activities of nano-iron metal and nano-iron oxides. J. Food Drug Anal. 2014, 22, 86-94. [CrossRef] [PubMed]

53. Bogdan, J.; Jackowska-Tracz, A.; Zarzyńska, J.; Pławińska-Czarnak, J. Chances and limitations of nanosized titanium dioxide practical application in view of its physicochemical properties. Nanoscale Res. Lett. 2015, 10, 57. [CrossRef] [PubMed]

54. Day, R.M.; Suzuki, Y.J. Cell Proliferation, Reactive Oxygen and Cellular Glutathione. Dose Response 2006, 3 , 425-442. [CrossRef] [PubMed]

55. Wu, H.-Y.; Chung, M.-C.; Wang, C.-C.; Huang, C.-H.; Liang, H.-J.; Jan, T.-R. Iron oxide nanoparticles suppress the production of IL-1beta via the secretory lysosomal pathway in murine microglial cells. Part. Fibre Toxicol. 2013, 10, 46. [CrossRef]

56. Britton, L.J.; Bridle, K.; Jaskowski, L.-A.; He, J.; Ng, C.; Ruelcke, J.E.; Mohamed, A.; Reiling, J.; Santrampurwala, N.; Hill, M.M.; et al. Iron Inhibits the Secretion of Apolipoprotein E in Cultured Human Adipocytes. Cell. Mol. Gastroenterol. Hepatol. 2018, 6, 215-217.e8. [CrossRef] [PubMed]

57. Veronesi, B.; Makwana, O.; Pooler, M.; Chen, L.C. Effects of subchronic exposures to concentrated ambient particles. VII. Degeneration of dopaminergic neurons in Apo E $\mathrm{E}^{-/-}$mice. Inhal. Toxicol. 2005, 17, $235-241$. [CrossRef] [PubMed]

58. Halle, A.; Hornung, V.; Petzold, G.C.; Stewart, C.R.; Monks, B.G.; Reinheckel, T.; Fitzgerald, K.A.; Latz, E.; Moore, K.J.; Golenbock, D.T. The NALP3 inflammasome is involved in the innate immune response to amyloid-beta. Nat. Immunol. 2008, 9, 857-865. [CrossRef] [PubMed]

59. Qi, Y.; Wang, J.K.; McMillian, M.; Chikaraishi, D.M. Characterization of a CNS cell line, CAD, in which morphological differentiation is initiated by serum deprivation. J. Neurosci. 1997, 17, 1217-1225. [CrossRef]

60. Lojk, J.; Čibej, U.; Karlaš, D.; Šajn, L.; Pavlin, M. Comparison of two automatic cell-counting solutions for fluorescent microscopic images. J. Microsc. 2015, 260, 107-116. [CrossRef]

61. Lojk, J.; Repas, J.; Veranič, P.; Bregar, V.B.; Pavlin, M. Toxicity mechanisms of selected engineered nanoparticles on human neural cells in vitro. Toxicology 2020, 432, 152364. [CrossRef]

(C) 2020 by the authors. Licensee MDPI, Basel, Switzerland. This article is an open access article distributed under the terms and conditions of the Creative Commons Attribution (CC BY) license (http://creativecommons.org/licenses/by/4.0/). 